\title{
Integrated Online Learning Module Development Macromedia Flash On Structuring Lessons of Traditional Buns arrangement
}

\author{
May Sarah \& Rahmiati \\ Pascasarjana Pendidikan Teknologi dan Kejuruan, Universitas Negeri Padang \\ mays76751@gmail.com
}

\begin{abstract}
This research aims to analyze and describe the design of online learning modules integrated macromedia flash that is feasible, practical and effective to be used in the lessons of traditional bun arrangement. This research includes a type of development research with the target is students of grade XI SMK Private PAB Medan. The research data was collected through validation sheets, student response questionnaires as well as tests. Data analysis techniques used are quantitative and qualitative data analysis and t-test. The results obtained: (1) macromedia flash integrated online learning module developed with 4-D model(define, design, develop and disseminate), module designed in PDF format with sizeA4 (21 $\times$ $29.7 \mathrm{~cm}$ ) and integrated macromedia flash that can be accessed and downloaded by students online through Google Classroom application; (2) the integrated online learning module macromedia flash developed has been declared valid and practically used in the learning of traditional bun arrangement; and (3) The resulting macromedia flash integrated online learning module is also stated to be effective in the learning of traditional bun arrangement and proven from the results of hypothesis testing with $\mathrm{t}$-count $>\mathrm{t}$-table value of $3,761>2.00$ and sig. $0.000<0.05$.
\end{abstract}

Kata Kunci: Online Learning, Module, Macromedia Flash,Model4-D.

\begin{tabular}{ll}
\hline Article History & Received : August $7^{\text {th }} 2020$ \\
& Revision : October $11^{\text {th }} 2020$ \\
& Publication : Dec $30^{\text {th }} 2020$ \\
\hline
\end{tabular}

\section{INTRODUCTION}

Hair is a crown for the owner, and one element of judgment of a person's appearance especially for a woman. In general, women in various regions in Indonesia, in ancient times had long hair, so that to look beautiful and beautiful the women styled their hair in accordance with the characteristics and characteristics of their respective regions. The socioeconomic level and position of a person in society such as nobles, queens, concubines and ordinary people can be symbolized or known through his hairdressing.

Conventional hairstyles in Indonesia that can be found are regional buns. Various kinds of regional buns are Indonesian cultural heritage that need and must be preserved, and are still often used in the implementation of traditional 
weddings or certain events that are still traditional. One type of traditional bun that is very unique is dendeng buns originating from West Kalimantan, especially in the Ketapang Regency area.

The uniqueness of this traditional bun can be seen from the shape and way of arranging it. The traditional bun is formed by folding and crossing the length across the border of the left and right edges above the head so that it is ribbonshaped and at the same time will be free-shaped on the left and right, it is also upright not lying down or sleeping. To add beauty, traditional buns are decorated or special ornaments that are mogan (pandanus leaves affixed jasmine flowers around it), jasmine flower arrangements and rocking flowers Kalimantan. Historically, the form of traditional buns was influenced by many Dayak Islam tribes who in the past were everyday buns of women who were generally long haired, and worn by women of noble descent only. But nowadays traditional buns are only worn by brides on her wedding day. The word traditional has the meaning of plastered (Rostamailis, 2008)

Traditional and creative sanggung arrangement is one of the subjects taught and must be mastered by students in grade XI SMK in the Beauty System Skills Program. In accordance with the 2013 curriculum, these subjects are taught with the aim that students have the knowledge, skills and skills to organize traditional buns. In addition, skills and skills in hair styling and buns also provide economic value, especially job opportunities in the world of regional and creative hair beauty today.

Based on the 2013 curriculum there are various types of traditional or regional buns that have been standardized and must be studied by students and one of them is dendeng buns that come from Western Kalimantan, especially in Ketapang Regency. The main material of dendeng bun arrangement is taught in Class XI in even semester with basic competence, namely studying the arrangement of traditional buns and structuring traditional buns. Indicators to be achieved from the material arrangement of this traditional bun, among others: 1 ) deciphering the shape and design of traditional buns, 2) explaining the technique of structuring traditional buns, 3) explaining the function and purpose of using ornaments and accessories of traditional buns, 4) planning and identifying techniques to make traditional buns, 5) drawing up work plans for the arrangement of traditional buns, 6) forming traditional buns, 7) arranging traditional buns, and 8) installing ornaments of dendeng buns.

Traditional buns have a distinctive shape that is ribbon-shaped which is located to be perpendicular and symmetrical above or the top of the head, so to form or style traditional hair is required exercises and skills in order to produce a perfect form of traditional bun. In fact, there are still many students in grade XI 
SMK Beauty System Skills Program who still have difficulty in structuring traditional buns.

The results of initial observations and interviews through focus group discussion (FGD) to each of the 6 students of SMK Negeri 10 Medan, SMK Private PAB Medan and SMK Private Pariwisata Imelda Medan, found that generally students consider traditional bun arrangement materials, especially traditional buns are difficult lessons, students are also less motivated and lack the spirit to follow the learning of bun arrangement because of how to teach teachers who are less attractive or tend to use lectures, and the demonstrations conducted by teachers in front of the classroom only involve a few students, so that those who are not involved in the demonstration still do not understand well the steps of setting up the bun traditional, teachers also only use the media in the form of slides The results of the interview and FGD also found that the students are eager for teachers to use more interesting and innovative media so that students become spirit and the material learned can also be understood, remembered and mastered by students well.

Learning traditional bun arrangements for some students is considered a difficult lesson. Students' difficulties are due to limited learning time, learning resources, and some learning resources in the form of jobsheet hand outs and PowerPoint slides from teachers. Lack of mastery of the material described at the time of traditional bun structuring practice, where students must know all types and ornaments to be used. But the reality is, there are still many students who have not been able to remember correctly all the types and ornaments that will be used (Lubis, 2019).

In fact each student has different abilities, attitudes and characteristics. Some students are easy to understand the material by visual means, some are easy to understand by listening (auditory) and others are easy to understand the material by practicing or performing (kinesthetic). Therefore, teachers do not only use one method, but also have to be creative and innovative in choosing methods and using media that can encourage students to learn and make student learning more enjoyable.

The digital era 4.0 and the current Covid-19 pandemic outbreak, which requires students to continue learning from home by utilizing the internet also encourage educational institutions or schools including vocational schools to continue to innovate and improve the abilities mastered by their graduates. Based on this and the problems faced in learning the arrangement of traditional buns, especially traditional buns, makes researchers feel challenged to innovate by developing a learning module integrated macromedia flash and accessible to students online (online) that students are expected to learn, when and wherever students are.

Modules are teaching materials systematically designed according to the age and level of knowledge of students in order to learn independently(Prastowo, 2003), helping students achieve learning goals(Sukirman, 2012), without the 
presence of teachers(Smaldino, 2012). The development and use of learning modules has also been proven to improve the quality of learning.

Some studies have shown that the learning modules developed are considered feasible and that there is an increase in concepts between students using modules and those who do not(Lasmiyati, 2014), effective learning modules in supporting learning activities(Prabowo, 2016), improving student learning outcomes (Lubis, 2019; Suryanto, 2017; Setiyadi, 2017), can be used as a learning resource that helps students learn independently (Sari, 2019).

Modules to be developed in this research are traditional bun structuring modules made in PDF format(Portable Document Format)and integrated mediabased macromedia flash. Macromedia flash is a software that can display or create very interesting animations, one of which is making teaching devices. This software is also equipped with action scripts (action commands) so that the teaching devices created will be effectively used in the learning process and of course will be more interesting than other learning media(Andreas, 2013).

Development and use of macromedia flash-based media in learning is also proven to be able to improve the quality of learning. Some previous studies have concluded that macromedia flash-based learning media is effectively used in learning (Prastowo, 2014), used as a learning medium(Priyonggo, 2018), effectively to improve learning outcomes (Sari, 2014).

Some of the advantages of integrated multimedia learning modules that will be developed in this research, including: 1) modules are created in PDF format and uploaded in the Google Classroom application so that students can be accessed and downloaded online through a computer, laptop or smartphone using the internet network; 2) can attract the attention and motivation of students to learn through the existing macromedia flash; 3) students can learn and understand the material easily and perform the working steps of setting up a traditional bun with the presence of media; 4) students can learn independently even if they have to keep learning from home; 5) can help students improve their understanding and skills as students can repeat the material anytime and anywhere; and 6) can help teachers in delivering materials remotely online due to the current Covid-19 pandemic that requires students to continue learning from home. Online learning module integrated macromedia flash that will be developed in this research, is also expected to be able to improve the quality of learning, especially in the learning of traditional bun arrangement grade XI SMK Beauty System Skills Program.

\section{METHOD}

This research includes the type of research and development (Research and Development). Research and development is a process used to develop and validate educational products(Setyosari, 2016), testing the effectiveness of such 
products(Sugiyono, 2017), which can be accounted for(Saodih, 2010). In this research, product development focused on macromedia flash integrated online learning module in traditional bun arrangement lessons (Traditional) in VOCATIONAL. The development model used was the 4-D development model presented by Thiagarajan and Semmel(Trianto, 2014), covering four stages: define, design, develop, and disseminate.

The subject of this development research consists of: instrument validator; expert validators (material experts and media experts); teacher; and students of Private Vocational High School PAB Medan. While the object of this research is an integrated online learning module macromedia flash on the lessons of setting the bun Traditional. Data collection techniques and instruments using interviews, validation sheets, questionnaires and test instruments. The data of the research results were analyzed through several stages including: validity analysis, practicality analysis and effectiveness analysis with t-test techniques using independent Sample T-test approach with the help of SPSS program.

\section{RESULT_AND DISCUSSION}

The result of this research and development is an online learning module integrated macromedia flash in the learning of sanggung Dendeng grade XI SMK Beauty System Skills Program that has been declared valid, practical and effective to be used in the learning of traditional buns.

Macromedia Flash Integrated Online Learning Module Design

Macromedia flash integrated online learning module in traditional bun setup lessons developed with 4-D development model includes define (definition), design, develop, and disseminate stages. Design (design)products done after going through the process of defining (define)include: front and analysis ( front and analysis),student analysis(learner analysis), task analysis(task analysis), concept analysis(concept analysis)and the formulation of objectives (specifying instructional objectives). After going through the process of defining ( define), the initial product (prototype) is designed in the form of an integrated online learning module macromedia flash, which is designed attractively, the format or form of presentation is adjusted to the material and material arrangement of traditional buns. 


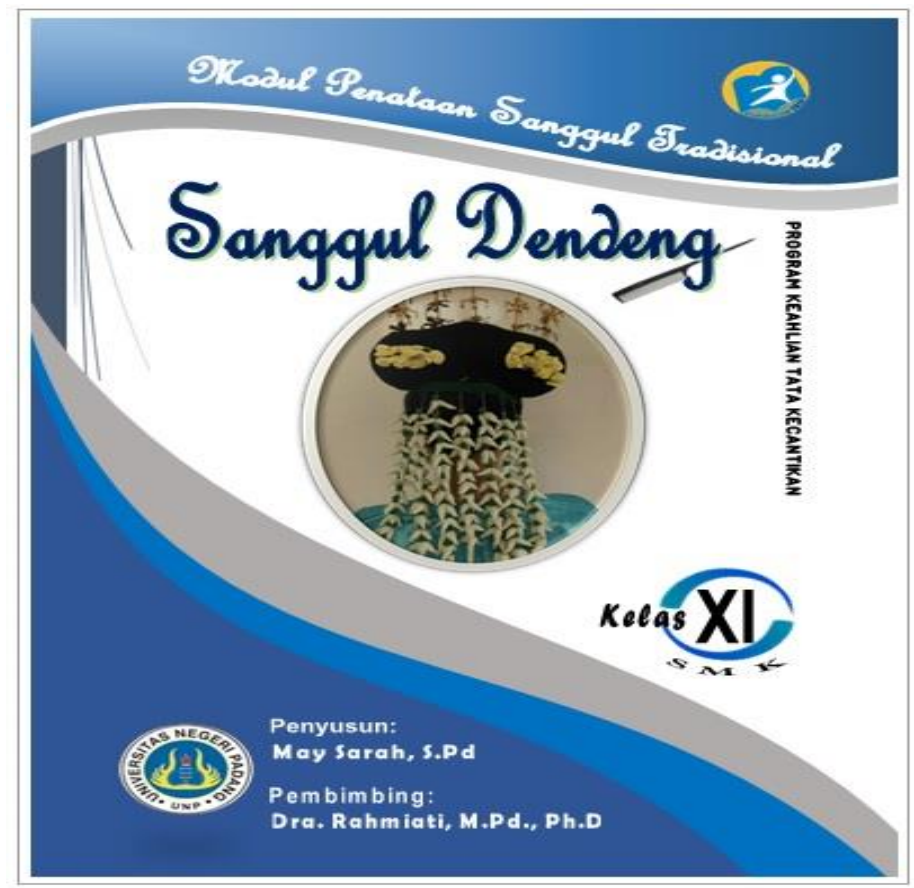

Figure 1. Online Learning Module Initial Design (Module Cover)

The learning module is designed to be accessible to students online (online) through the Google Classroom application and is created in PDF format(Portable Document Format)with a size of A4 $(21 \times 29.7 \mathrm{~cm})$ with the aim of making it easier for students to use. This online learning module is designed to integrate with macromedia flash, so that students can understand more easily and easily remember concepts or materials as well as steps to arrange traditional buns presented in modules and integrated macromedia flash, because macromedia flash developed is equipped with instructions for use, material description and video about the working steps of structuring the traditional bun.

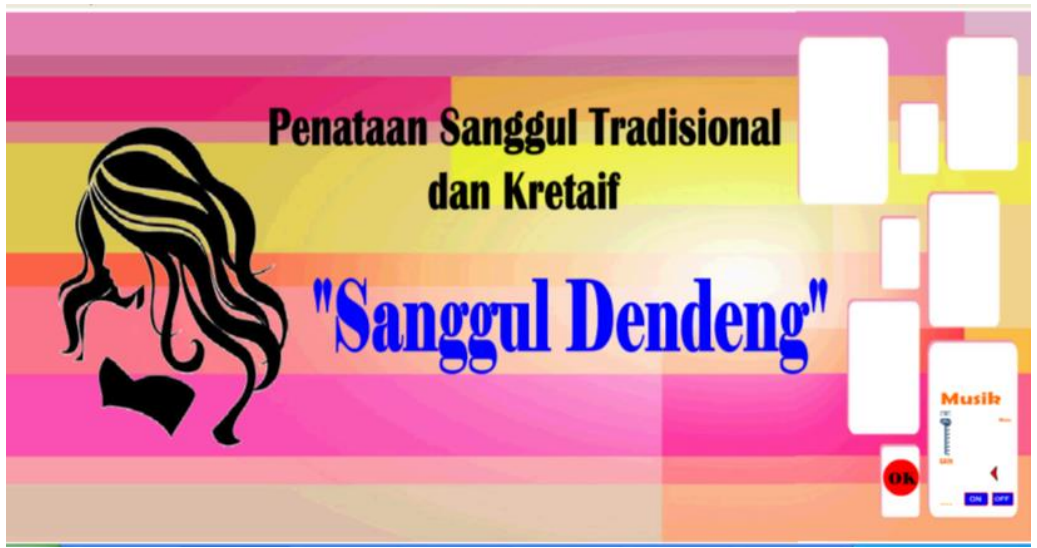

Figure 2. Macromedia Flash Initial Design/Display

This macromedia flash is also uploaded on the Google Classroom app to be accessible and downloaded by students online, helping students to learn independently, foster motivation, passion and students' creativity in learning, as 
well as students can repeat the material and understand the practice of structuring dendeng buns anywhere and anytime.

\section{Feasibility and Practicality of Macromedia Flash}

The feasibility of macromedia flash integrated online learning modules is obtained from validation results (assessments) carried out by expert validators, while the practicality of macromedia flash integrated online learning modules is obtained through development trials conducted to target users, namely students.

1. Expert Validation Results

Macromedia flash integrated online learning modules that have been designed are further validated by expert validators (material experts and media experts) to test their feasibility or validity.

Table 1. Online Learning Module Validation Results on Material Aspects

\begin{tabular}{|c|l|c|l|}
\hline No. & \multicolumn{1}{|c|}{ Assessment Aspects } & Average Score & \multicolumn{1}{c|}{ Criteria } \\
\hline 1 & Content Eligibility & 4,50 & Very Valid \\
\hline 2 & Language Eligibility & 4,29 & Very Valid \\
\hline 3 & Presentation Eligibility & 4,60 & Very Valid \\
\hline 4 & Module Components & 4,73 & Very Valid \\
\hline & Overall Average & $\mathbf{4 , 5 7}$ & Very Valid \\
\hline
\end{tabular}

Based on the data in Table 1 above, it can be explained that the results of assessment (validation) by material expert validators in online learning modules obtained an average overall score of 4.57 or classified as very valid. In the aspect of content eligibility is declared very valid with an average score of 4.50; in the aspect of language eligibility is declared very valid with an average score of 4.29 , in the aspect of eligibility the presentation is declared very valid with an average score of 4.73; and in component aspects the module was declared very valid with an average score of 4.73 .

Table 2. Online Learning Module Validation Results on Media Aspects

\begin{tabular}{|c|l|c|l|}
\hline No. & \multicolumn{1}{|c|}{ Assessment Aspects } & Average Score & \multicolumn{1}{c|}{ Criteria } \\
\hline 1 & Graphics Quality & 5,0 & Very Valid \\
\hline 2 & Language Eligibility & 5,0 & Very Valid \\
\hline 3 & Module Cover & 5,0 & Very Valid \\
\hline 4 & $\begin{array}{l}\text { Feasibility of Modules as } \\
\text { Teaching Materials }\end{array}$ & 5,0 & Very Valid \\
\hline & \multicolumn{1}{|c|}{ Overall Average } & $\mathbf{5 , 0}$ & Very Valid \\
\hline
\end{tabular}

Based on the data in Table 2 above, it can be explained that the results of assessment (validation) by media expert validators obtained an average overall score of 5.0 or classified as very valid. In terms of graphics quality, language feasibility, module cover, module content, and module feasibility as teaching materials, each obtained an average score of 5.0 or declared very valid. 
The results of the assessment (validation) by expert validators (material experts and media experts) show that the online learning module that has been developed has been declared very valid (very feasible) reviewed from the material aspects (aspects of content feasibility, language feasibility, feasibility of presentation and aspects of module components) as well as media aspects (aspects of graphic quality, language feasibility, module cover/ cover, module content, and aspects of module feasibility as teaching materials).

Table 3. Macromedia Flash Validation Results On Material Aspects

\begin{tabular}{|c|l|c|l|}
\hline No. & \multicolumn{1}{|c|}{ Assessment Aspects } & Average Score & \multicolumn{1}{|c|}{ Criteria } \\
\hline 1 & Content Aspects & 3,88 & Valid \\
\hline 2 & Material Display/Accuracy & 4,00 & Valid \\
\hline 3 & $\begin{array}{l}\text { Quality and Effectiveness of } \\
\text { Materials }\end{array}$ & 4,43 & Very Valid \\
\hline & \multicolumn{1}{|c|}{ Overall Average } & $\mathbf{4 , 1 0}$ & Valid \\
\hline
\end{tabular}

Data in Table 3 above, it can be explained that the results of assessment (validation) by the validator of material experts in macromedia flash obtained an average overall score of 4.10 or classified as valid criteria. In the content aspect is declared valid with an average score of 3.88; on the display/accuracy aspect of the material is declared valid with an average score of 4.0; and in terms of quality and effectiveness of the material is declared very valid with an average score of 4.43.

Table 4. Macromedia Flash Validation Results on Media Aspects

\begin{tabular}{|c|l|c|l|}
\hline No. & \multicolumn{1}{|c|}{ Assessment Aspects } & Average Score & Criteria \\
\hline 1 & Media Aspects & 4,25 & Very Valid \\
\hline 2 & Program View & 4,83 & Very Valid \\
\hline 3 & $\begin{array}{l}\text { Technical Quality and Program } \\
\text { Effectiveness }\end{array}$ & 4,90 & Very Valid \\
\hline & \multicolumn{1}{|c|}{ Overall Average } & $\mathbf{4 , 7 5}$ & Very Valid \\
\hline
\end{tabular}

Based on the data in Table 4 above, it can be explained that the results of assessment (validation) by the validator of media experts in macromedia flash developed obtained an average overall score of 4.75 or classified as very valid criteria. In the media aspect is declared very valid with an average score of 4.25; on the display aspect of the program is declared very valid with an average score of 4.83; and in terms of technical quality and effectiveness of the program was declared very valid with an average score of 4.90 . 
1. Development Trial Results

The trial of the development of integrated online learning module macromedia flash was conducted in two stages, namely individual trials (one-to-one trying out)to5 students and small group tryouts to 10 students.

Table 5. Online Learning Module Development Trial Results

\begin{tabular}{|c|c|c|c|c|c|}
\hline \multirow[b]{2}{*}{ No. } & \multirow[b]{2}{*}{ Assessment Aspects } & \multicolumn{2}{|c|}{ Individual } & \multicolumn{2}{|c|}{ Small Group } \\
\hline & & $\begin{array}{l}\text { Average } \\
\text { Score }\end{array}$ & Criteria & $\begin{array}{c}\text { Average } \\
\text { Score }\end{array}$ & Criteria \\
\hline 1 & Product Results & 4,00 & Good & 3,89 & Good \\
\hline 2 & $\begin{array}{l}\text { Effectiveness for } \\
\text { Students }\end{array}$ & 3,89 & Good & 3,83 & Good \\
\hline & Overall Average & 3,95 & Good & 3,86 & Good \\
\hline
\end{tabular}

Based on the data in Table 5 above, it can be explained that the results of individual development trials to 5 students for online learning modules, obtained an average overall score of 3.95 or classified as good criteria. In terms of product results are classified as good criteria with an average score of 4.00 and in the effectiveness aspect for students classified as good criteria with an average score of 3.89. Small group trial results to 10 students, obtained an average overall score of 3.86 or relatively good. In terms of product results, the criteria are good with an average score of 3.89 and in the effectiveness aspect for students is classified as good with an average score of 3.83 .

Table 6. Macromedia Flash Development Trial Results

\begin{tabular}{|c|l|c|c|c|c|}
\hline \multirow{2}{*}{ No. } & \multirow{2}{*}{ Assessment Aspects } & \multicolumn{2}{|c|}{ Individual } & \multicolumn{2}{c|}{ Small Group } \\
\cline { 3 - 6 } & $\begin{array}{c}\text { Average } \\
\text { Score }\end{array}$ & Criteria & $\begin{array}{c}\text { Average } \\
\text { Score }\end{array}$ & Criteria \\
\hline 1 & Product Results & 3,95 & Good & 3,74 & Good \\
\hline 2 & $\begin{array}{l}\text { Effectiveness for } \\
\text { Students }\end{array}$ & 3,54 & Good & 3,47 & Good \\
\hline & \multicolumn{1}{|c|}{ Overall Average } & $\mathbf{3 , 7 6}$ & Good & $\mathbf{3 , 6 1}$ & Good \\
\hline
\end{tabular}

Based on the data in Table 6 above, it can be explained that the results of individual development trials to 5 students for macromedia flash, obtained an average overall score of 3.76 or classified as good criteria. In terms of product results, the average score is 3.95 and the effectiveness aspect for students is relatively good with an average score of 3.54. Small group trial results to 5 students, obtained an average overall score of 3.61 or classified as good criteria. In terms of product results, the average score is 3.74 and the effectiveness aspect for students is good with an average score of 3.47 . 
Thus, based on the validation results by expert validators (both material experts and media experts) and the results of development trials (both individually and in small groups) it can be concluded that the integrated online learning module macromedia flash on the lesson of structuring traditional buns developed has met the criteria valid (feasible) and practical to be used in the process of learning the arrangement of buns Traditional grade XI SMK Beauty System Skills Program. Validity (feasibility) has been fulfilled qualitatively based on the assessment of expert validators who on average are classified as very valid. Practicality has also been met qualitatively based on the student's response to the results of the development trial conducted to the students and overall the average is classified as good criteria (practical).

\section{Effectiveness of Macromedia Flash Integrated Online Learning Module}

The effectiveness of macromedia flash integrated online learning modules can be analyzed by comparing student learning achievement results using macromedia flash integrated online learning modules (experimental groups) with students without using macromedia flash integrated online learning modules (comparison/control groups). Effectiveness is analyzed using Pretest-Posttest Control Group Design. The description of the pretest data and the post-test data of both sample groups, are summarized briefly in Table 7.

Table 7. Description of Student Pretest and Post-test Data

\begin{tabular}{|l|r|r|r|r|}
\hline \multirow{2}{*}{ Statistics } & \multicolumn{2}{|c|}{ Ready } & \multicolumn{2}{c|}{ Posts } \\
\cline { 2 - 5 } & Experiment & \multicolumn{1}{c|}{ Control } & Experiment & \multicolumn{1}{c|}{ Control } \\
\hline $\begin{array}{l}\text { N (Number of } \\
\text { Students) }\end{array}$ & 30 & 30 & 30 & 30 \\
\hline Mean & 49,73 & 48,67 & 84,27 & 76,67 \\
\hline Std. Deviation & 9,836 & 12,521 & 7,348 & 8,277 \\
\hline Variance & 96,754 & 156,782 & 53,995 & 68,506 \\
\hline Minimum & 32 & 28 & 68 & 56 \\
\hline Maximum & 76 & 80 & 100 & 92 \\
\hline Sum of Values & 1492 & 1460 & 2528 & 2300 \\
\hline
\end{tabular}

Based on the data in Table 7 above, it can be explained that for students of the experimental class obtained an average pretest score of 49.73 and a standard deviation of 9,836 with the lowest score of 32 and the highest score of 76; while control class students obtained an average pretest score of 48.67 and a standard deviation of 12,521 with a low score of 28 and a top score of 80 . Post-test results for experimental class students using macromedia flash integrated online learning modules obtained an average post-test score of 84.27 and a deviation standard of 7,348 with the lowest score of 68 and the highest score of 100; while the control 
class students (comparison) obtained an average post-test score of 76.67 and a standard deviation of 8,277 with the lowest score of 56 and the highest score of 92 .

Further effective use of macromedia flash integrated online learning modules can also be analyzed with t-tests or by Independent Sample T-test approach using the help of SPSS program.

Table 8. T-test Results (Independent Sample T-test)

\begin{tabular}{|l|r|r|r|r|l|}
\hline & \multicolumn{1}{|c|}{ T } & \multicolumn{1}{|c|}{ df } & $\begin{array}{c}\text { Sig } \\
\text { (2-tailed) }\end{array}$ & \multicolumn{1}{c|}{ t-table } & Description \\
\hline Posts & 3,761 & 58 & 0,000 & 2,00 & Significant \\
\hline
\end{tabular}

Based on the data in Table 8 above, it can be explained that the result of analysis of post-test data, obtained t-count value $>$ t-table is 3,761 $>2.00$ and sig value. $0.000<0.05$ so that it can be concluded that there is a difference in average post-test value or student learning results after being given different learning that is the experimental class is given learning using macromedia flash integrated online learning module while the control class is given regular learning without integrated online learning module macromedia flash.

Thus, based on the results of post-test and t-test analysis it was concluded that the integrated online learning module macromedia flash is effectively used in the learning of traditional bun arrangement, where the average value of learning outcomes (post-test) of experimental class students using macromedia flash integrated online learning modules is 84.27 while control class students obtained an average score of 76.67. These results indicate that the use of macromedia flash integrated online learning modules is better and more effective than without using macromedia flash integrated online learning modules with an average difference in student post-test score of 7.60 .

\section{CONCLUSION}

The findings of research and development that have been done, obtained some conclusions as follows:

1. The resulting product of this research and development is an integrated online learning module macromedia flash in the lesson of setting up a bun Traditional class XI SMK Beauty System Skills Program. The product is developed with a 4$\mathrm{D}$ development model(define, design, develop and disseminate). The learning module is designed and created in PDF format(Portable Document Format)with a size of A4 $(21 \times 29.7 \mathrm{~cm})$ and integrated macromedia flash that students can access or download online through the Google Classroom application.

2. Macromedia flash integrated online learning module developed has been declared valid and practically used in the learning of traditional bun arrangement. Eligibility (validity) has been fulfilled qualitatively based on the assessment of expert validators (material experts and media experts) who on 
average are classified as very valid criteria. Practicality has also been met qualitatively based on the results of development trials (individual trials and small group trials) and overall the average student response is classified as good (practical) criteria.

3. The resulting macromedia flash integrated online learning module is also effectively used in the learning of traditional bun arrangement in grade XI SMK Beauty System Skills Program. Effectiveness was met based on the average post-test score that is for the students of the experiment class obtained an average post-test score of 84.27 while for control class students obtained an average post-test score of 76.67. The effectiveness of the product is also proven from the hypothetical test results with the value of $\mathrm{t}$-count $<\mathrm{t}$-table which is $3,761<2.00$ and sig value. $0.000<0.05$.

\section{Author Biodata}

MaySarah, born in Medan, May 01, 1996. Completed S1 Program of Makeup Education, Department of Family Welfare Education, Faculty of Engineering, Medan State University (UNIMED) in 2018. He is now a graduate student of Technology and Vocational Education, Faculty of Engineering, Padang State University.

Rahmiati,born in Padang, 04 September 1962. Completed S1 Department of Fashion IKIP in 1986, S2 Department of Vocational Technology Education, IKIP Yogyakarta in 1997, and S3 Department of Technology and Vocational Education Universitas Kebangsaan Malaysia in 2018. He is currently a Lecturer of Postgraduate Program of Technology and Vocational Education, Faculty of Engineering, Padang State University.

\section{REFERENCES}

A. Prastowo, I.M. Nauri, dan Mustamam(2014). Pengembangan Media Pembelajaran Berbasis Macromedia Flash 8.0 Pada Kompetensi Dasar Mengidentifikasi Kelistrikan dan Instrumen Sepeda Motor Untuk Siswa Kelas XI Jurusan Teknik Otomotif Sepeda Motor di SMK Negeri 9 Malang. Jurnal Teknik Mesin. 22(2).

A. Prastowo (2013). Panduan Kreatif Membuat Bahan Ajar Inovatif. Yogyakarta: Diva Press,.

A.S. Andreas(2013). Menguasai Pembuatan Animasi dengan Flash MX. Jakarta: Elex Media Komputindo,.

A.T.A. Yori, Purwandari, dan S. Kartikawati. (2017) Pengaruh Penerapan Media Pembelajaran Macromedia Flash Berbasis Problem Solving Untuk 
Meningkatkan Hasil Belajar Mahasiswa Pada Mata Kuliah Proteksi Sistem Tenaga Listrik. JUPITER (Jurnal Pendidikan Teknik Elektro). 2(2): 1-6,

E.S. Smaldino, D.L. Lowther, and J.D. Russell (2011). Instructional Technology and Media of Learning: Teknologi Pembelajaran dan Media Untuk Belajar. (Alih Bahasa; Arif Rahman). Jakarta: Pranada Media Group.

F.A. Sari, N. Suseno (2019), dan Riswanto. Pengembangan Modul Fisika Online Berbasis Web pada Materi Usaha dan Energi. JIPFRI Uurnal Inovasi Pendidikan Fisika dan Riset Ilmiah). 3(2): 129-135.

F.V. Priyonggo, dan A. Qosyim. (2018) Pengembangan Media Pembelajaran Interaktif Berbasis Macromedia Flash Untuk Materi Sistem Gerak Pada Manusia Kelas VIII. Ejournal-Pensa. 06(02)

I.N. Sari, S. Saputro, dan Ashadi (2013). Pengembangan Multimedia Pembelajaran Berbasis Macromedia Flash Sebagai Sumber Belajar Mandiri Pada Materi Koloid Kelas XI IPA SMA dan MA. Jurnal Pendidikan Kimia (JPK). 2(3).

Lasmiyati dan I. Harta (2014). Pengembangan Modul Pembelajaran Untuk Meningkatkan Pemahaman Konsep dan Minat SMP. PYTHAGORAS: Jurnal Pendidikan Matematika. 9(2): 161-174.

M.W. Setiyadi, Ismail, dan H.A. Gani (2017). Pengembangan Modul Pembelajaran Biologi Berbasis Pendekatan Saintifik Untuk Meningkatkan Hasil Belajar Siswa. Jorunal of Educational Science and Technology. 3(2): 102-112

N. Saodih (2010). Metode Penelitian Pendidikan. Bandung: Remaja Rosdakarya.

P. Setyosari (2013). Metode Penelitian Pendidikan dan Pengembangan. Jakarta: Kencana Prenada Media Group.

Prabowo, Ibrohim, dan M. Saptasari (2016). Pengembangan Modul Pembelajaran Inkuiri Berbasis Laboratorium Virtual. Jurnal Pendidikan, Teori, Penelitian dan Pengembangan. 1(6): 1090-109.

Rostamailis, Hayatunnufus dan M. Yanita (2008). Tata Kecantikan Rambut Jilid 2 Untuk SMK. Jakarta: Direktorat Pembinaan Sekolah Menengah Kejuruan, Direktorat Jenderal Manajemen Pendidikan Dasar dan Menengah, Departemen Pendidikan Nasional.

S.F. Lubis, Ellizar, dan Sukardi (2019). Development of Traditional Bun Arrangement Module for $11^{\text {th }}$ Grade Students in State Vocational High School. Budapest International Research and Critics in Linguistics and Education (BirLE) Journal. 2(4): 329-337.

Sugiyono (2013). Metode Penelitian Pendidikan: Pendekatan Kuantitatif, Kualitatif, dan R\&D. Bandung: Alfabeta.

Sukiman (2012). Pengembangan Media Pembelajaran. Yogyakarta: Pustaka Insan Madani.

Suryanto, M.S. Zulela, A. Noornia, dan V. Iasha (2017). Pengembangan Modul Pembelajaran Matematika Berbasis Penemuan Terbimbing Tentang 
Pengukuran di Kelas IV Sekolah Dasar. Jurnal Pendidikan Dasar. 8(2): 124134

Trianto (2014). Desain Pengembangan Pembelajaran Tematik. Jakarta: Bumi Aksara. 